\title{
COMBINING SENSORS IN LANDSCAPE ECOLOGY: IMAGERY-BASED AND FARM-LEVELANALYSIS IN THE STUDY OF HUMAN-DRIVEN FOREST FRAGMENTATION
}

\section{Combinando sensores em geoecologia: sensoriamento remoto e análise sócio-econômica de propriedades rurais no estudo da fragmentação florestal antrópica}

\author{
Diogo de Carvalho Cabral \\ Mestre em História Social pela UFRJ \\ diogocabral@superig.com.br \\ Simone R. Freitas \\ simonerfreitas.usp@gmail.com \\ Judith Tiomny Fiszon \\ Doutora Pesquisadora Associada da Fundação Oswaldo Cruz \\ jtfiszon@openlink.com.br
}

Artigo recebido para publicação em 21/05/2007 e aceito para publicação em 09/08/2007

RESUMO: $\quad$ Apesar de os métodos de sensoriamento remoto serem capazes de fornecer bases confiáveis para a identificação da quantidade e da configuração espacial do desflorestamento, eles não podem, sozinhos, explicar suas causas. Para isso, precisamos complementar a análise de imagens com dados sócio-econômicos advindos de levantamentos de campo ao nível da unidade produtivo-domiciliar, pois estas afetam processos como a migração, uso da terra e escolhas técnicas. Deste modo, ao combinarmos imageamento remoto e levantamento sócio-econômico de campo, obtemos um arcabouço metodológico híbrido com potencial de aumentar nossa capacidade de conhecer os determinantes da fragmentação florestal. Nós apresentamos um modelo metodológico desse tipo para o estudo do desflorestamento da Mata Atlântica. Dois estudos empíricos - uma análise por sensoriamento remoto e outro baseado em levantamento de campo - foram sobrepostos no contexto de um projeto de pesquisa mais amplo enfocando a fragmentação florestal no nordeste da região hidrográfica da Guanabara, Rio de Janeiro. Mostramos que, mais do que metodologias do tipo "colcha-de-retalhos", precisamos de esquemas teoricamente informados que dêem sentido ao uso de diferentes abordagens $e$ métodos geoecológicos para documentar e interpretar as mudanças de uso da terra.

Palavras-chave: sensoriamento remoto; levantamento sócio-econômico de campo; metodologia geoecológica; fragmentação florestal; Mata Atlântica.

ABSTRACT: Although remote sensed methods provide reliable basis for identifying the amount and spatial configuration of deforestation, they cannot solely explain its underlying causes. For that, we need to complement the imagery analysis with socio-economic data from household or farmlevel studies, because these domestic units affect process such migration, land-use, and technology choice. Thus, by combining remote imagery sensor and social survey, we obtain a 
Combining sensors in landscape ecology: imagery-based and farm-level analysis in the study of human-driven forest fragmentation Diogo de Carvalho Cabral, Simone R. Freitas, Judith Tiomny Fiszon

merged analytical framework, which has the potential to improve our understanding on the determinants of human-driven forest fragmentation. We present such a methodological framework for studying deforestation in the Brazilian Atlantic Forest. Two empirical studies - a remote sensing analysis and a farm-level survey - were put together in the context of a wider project focusing on forest fragmentation process in the northeastern Guanabara region, Rio de Janeiro, Brazil. We show that, rather than 'patchwork quilt' methodologies, we need theoretical-oriented frameworks that give sense to the use of different landscape ecological approaches and methods (imagery analysis, mathematical modeling and social studies) in order to document and interpret land-use changes.

Keywords: remote sensing; farm-level survey; landscape research methodology; forest fragmentation; Brazilian Atlantic Forest.

\section{INTRODUCTION}

Sensors can be defined as technical-methodological devices that import/collect raw empirical data, organize it through a primary model and export it as codified information. Within the research process, these devices must coherently articulate with theoretical elements in order to make intelligible certain specific objects of reality. Because real objects are complex and multidimensional, there is often a need to aggregate and articulate various types of sensors.

Deforestation and forest fragmentation is a good example. Remote sensors (including not only space-imagery systems, but also side-looking radar and aerial photography) are obviously very useful to evaluate deforestation, especially in tropical regions (Myers 1988; Freitas et al. 2005; Freitas and Shimabukuro in press). Though imagery resources can provide a reliable basis for measuring the amount and spatial configuration of forest clearing and exploitation, they cannot solely explain why deforestation occurs (Wood and Skole 1998). To understand why, we need to identify and model the social determinants of deforestation. Remote sensing outputs (thematic maps, GIS analyses) with its grid-cell maps must be linked with economics, politics, sociology, and other disciplines within the social sciences (Wood and Skole 1998).

The fundamental problem in this transition is that the unit of observation of remote sensors is a pixel, which does not correspond in any straightforward fashion to social, economic or political units of human organization (Mertens et al. 2000). Solving this problem requires not only having reliable data of different origins and formats, but also and mainly, the articulation of different methodological frameworks (Rindfuss and Stern 1998). On the one hand, we have social science methods using in situ sensors such as comprehensive interviews, quantitative household surveys, participative or non-participative observation or interpretation of historical records (see e.g., Almeida 1992; Marquete 1998). On the other hand, we have modern methods of remote sensing and computer-based interpretation and modeling (see e.g., Skole and Tucker 1993; Metzger 2002; Batistella et al. 2003).

Studies at the household or farm level, such as those traditionally used by social scientists, are useful in answering questions about the underlying causes of deforestation because households are the actual decision makers in processes such as migration, land clearing, land-use and choice of technology (Andersen et al. 2002). However, landscape or regional level imagery-based studies respond to the needs for empirical results comparable among regions and countries; in addition, they can be used to improve the modeling on global land change dynamics (Wood and Skole 1998; Turner II et al. 2001). 
Consequently, it is judicious to assert that, for combining sensors with different limitations and imperfections, an analytical framework that combines remote sensing and Social Science field methods has the potential to improve our understanding of the determinants of various types of land-cover changes (Rindfuss and Stern 1998). Regardless of how coherent and inspiring this statement can be, the linkage must be brought to the empirical level to transform it into a useful methodological principle. To do so, we need to answer some basic questions such as: What are the specific limitations of each kind of sensor? How can we reduce limitations by linking sensors with social processes? Through answering these and other questions we can extract the best and reject the worst of each kind of sensor.

Unfortunately, most recent attempts to empirically apply hybrid types of methodology (see Brondizio 1996; Fujisaka et al. 1996; Moran and Brondizio 1998; Sierra and Stallings 1998; Wood and Skole 1998; Mertens et al. 2000; Turner II et al. 2001) do not centrally address the methodological issues - although authors usually comment on them. In this paper we propose a methodological framework that combines remote sensing techniques and fieldbased social analysis by using the Southern Brazilian Atlantic Forest as a case study. Two empirical studies, a remote sensing analysis and a farm-level survey respectively, were combined in the context of a common wider project focusing on forest fragmentation process in the northeastern Guanabara region, Rio de Janeiro, Brazil. The central issue is the underlying methodological processes supporting these empirical findings rather than the findings themselves, which are discussed in more detail in Cabral and Fiszon (2004).

\section{METHODS}

\subsection{The empirical basis: northeastern Guanabara region, Rio de Janeiro}

The Brazilian Atlantic Forest has experienced a long history of human settlement and forest exploitation and conversion (Fonseca 1985; Dean
1996). Among the Brazilian States, originally covered by the Atlantic Forest, Rio de Janeiro experienced one of the most intensive processes of degradation (Dean 1996; Drummond 1997). This trend continues. Between 1990 and 1995, deforestation in Rio de Janeiro occurred at an annual average rate exceeding 28,000 hectares. Currently only $21 \%$ of the original forest cover exists in Rio de Janeiro state (BRASIL 1998). It has resulted in a landscape that congregates a few large-and-continuous forest patches generally situated over mountainous portions of the territory surrounded by many high-fragmentation zones (Tanizaki and Moulton 2000).

This study occurred in the Guapiaçú basin (fourth-order drainage channel), a $573.54 \mathrm{~km} 2$ area located in the northeastern Guanabara hydrographic region, which is entirely situated within the Rio de Janeiro state (Figure 1). The upper portion of the basin occurs in the oceanic escarpment of Serra do Mar, a mountainous system with a maximum of 2,000-2,200m and composed of a fissures block inclined to north-northeast direction. The basin also contains high-declivity hills which give way to the Guanabara plain (Almeida and Carneiro 1998). Ultimately, the basin discharges into the Guanabara Bay.

This area is located in the tropical zone, with a typical hot and dry climate (Nimer 1979; Amador 1997). The annual average temperature reaches $24^{\circ} \mathrm{C}$ in the coastal plain and $20^{\circ} \mathrm{C}$ in the mountainous regions. The precipitation annual averaged $2,000 \mathrm{~mm}$ in the Serra do Mar and oscillated between 1,000 and $1,500 \mathrm{~mm}$ in the Baixada Fluminense. Winter is characterized by the dry season, whereas summer is characterized by torrential rains (Amador 1997). The vegetation is characterized primarily by dense evergreen rainforest (IBGE 1991; Amador 1997).

Guapiaçú basin is located $100 \mathrm{~km}$ from the Rio de Janeiro district and is part of its rural-urban fringe (Souza 2003). The Basin contains part of Guapimirim and Cachoeiras de Macacu districts. Urban population of Guapimirim has grown from 18,446 inhabitants in 1991 to 25,593 inhabitants in 


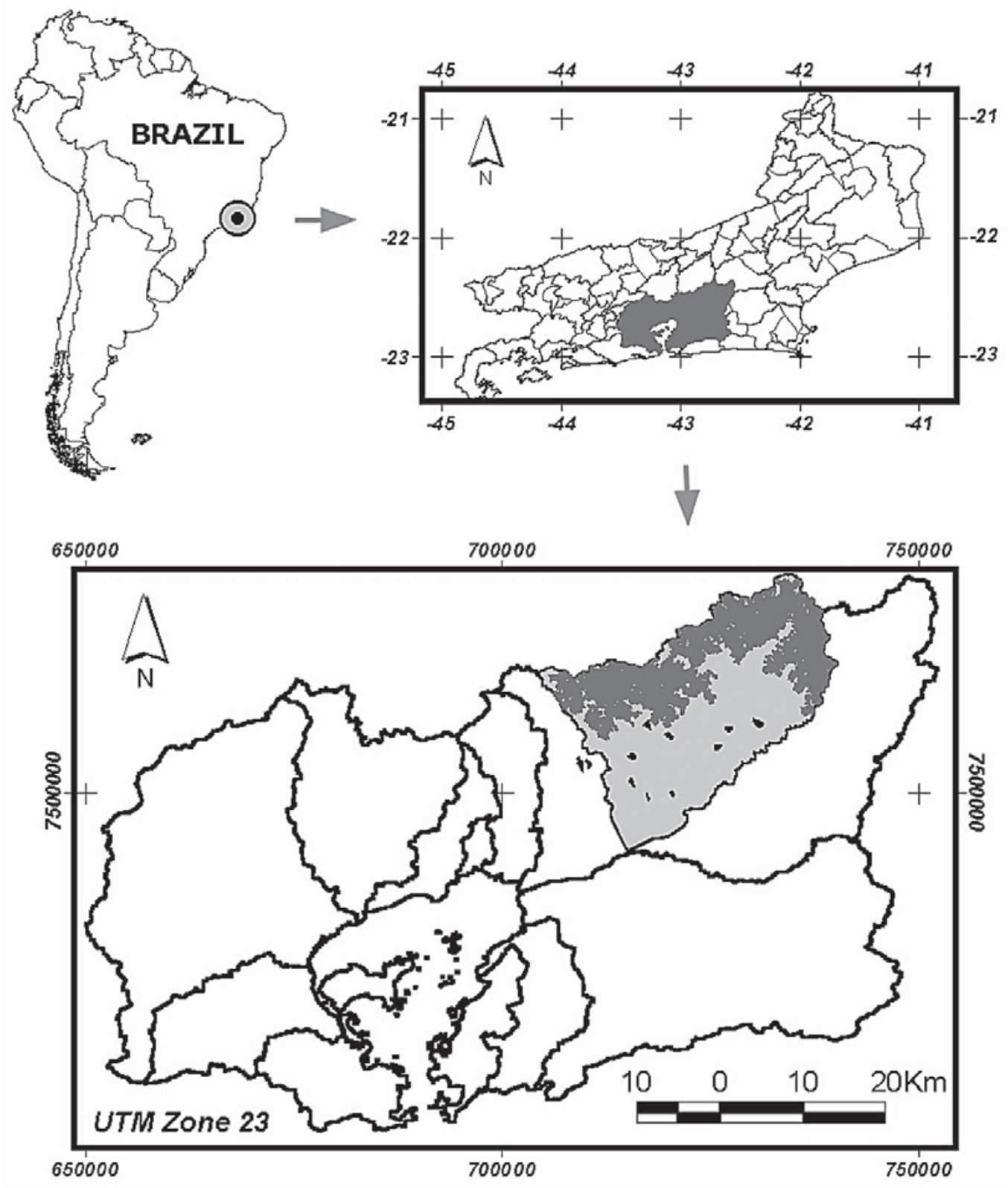

Figure 1. Location of the Guapiaçú basin in the Rio de Janeiro state, Southeastern Brazil.

2000 (a 39\% increase). By comparison, the rural population increased from 9,555 inhabitants in 1991 to 12,359 inhabitants in 2000 (a 29\% increase). This growth rate was higher than observed for the entire Rio de Janeiro State for the same time period (about $13 \%$ of growth of the urban population and a reduction of almost $6.5 \%$ of the residents in the rural area). The population growth of Guapimirim is very significant, especially in the rural area and differs from the retraction pattern observed for the State overall. For the same period from 1991 to 2000, urban population of Cachoeiras de Macacu increased from 32,036 to 41,117 inhabitants (a 28\% increase), whereas the population in the rural area declined from 8,172 to 7,426 inhabitants (a $9 \%$ decline). This decline was larger than observed for the entire State (IBGE 2003). 


\subsection{Remote sensing analysis}

Remote sensing analysis aims to spatially correlate the current forest fragmentation pattern to variables such as topography distribution, drainage network distribution and road network distribution, using a Landsat classified image, a stereoscopic interpretation of a historical set of aerial photographs and a Geographic Information System (GIS) analysis.

\subsubsection{Landsat 7 ETM+ image classification and analysis}

We used a Landsat 7 ETM+ image from February 28, 2000 (path 217/row 76). The six spectral bands of ETM+ sensor with 30m spatial resolution (bands 1, 2, 3, 4, 5 and 7) were registered through planimetrically correct maps, obtaining a 0.50 pixel precision. We used the Universal Transverse Mercator (UTM) projection with longitude origin at 45000 '00"W and datum SAD69. All image preprocessing procedures were done in SPRING, a stateof-the-art GIS developed by Brazil's National Institute for Space Research (INPE) and available for free on the web (INPE/DPI 2004).

To correct for atmospheric degradation, we used the Improved Chavez Method (Pax-Lenney et al. 2001). To classify the forest areas in a scene, we used the three first principal component bands and three mixture components (soil, vegetation and shadow) generated by the Linear Mixture Model procedure (Shimabukuro and Smith 1991; Lillesand and Kiefer 1994). The classification procedure was an image segmentation by region classifiers (similarity threshold $=8$ and least area $=10$ ) followed by an unsupervised algorithm (ISOSEG) and a supervised classification through Bhattacharya method. The image segmentation is a pixel clustering technique in which only nearby regions can be clustered based on their similarity and area thresholds (INPE/DPI 2004). We used the unsupervised and supervised classifications to classify the regions of a segmented image through training areas selected during field works.
To correlate forest cover distribution and topography, we applied a raster crossing function (COMBINE of Arc View 3.2 software) to the landuse classified image (only forest class) and the elevation classified image, with the following classes: 0-20m, 20-40m, 40-60m, 60-80m, 80-100m, 100$120 \mathrm{~m}, 120-140 \mathrm{~m}, 140-160 \mathrm{~m}, 160-180 \mathrm{~m}, 180-200 \mathrm{~m}$, 200-300m, 300-400m, 400-500m. The altitude classes differ in their amplitude (20 m steps up to $200 \mathrm{~m}$, then $100 \mathrm{~m}$ steps) because in the altitudes higher than 200m mainly forest covered the landscape, and a finer evaluation was no longer needed (Freitas 2004). For the drainage network distribution, we used six buffers at $100 \mathrm{~m}$ increments from the river. To evaluate the effects of the road network and the distance from Serra do Mar, a large-and-continuous forest patch, we used 10 buffers at $100 \mathrm{~m}$ increments. It was assumed that distances from the rivers above $600 \mathrm{~m}$ would not significantly affect the forest cover, in the same way that roads could significantly affect fragments up to distances of $1 \mathrm{~km}$. For each buffer increment, we calculated forest cover and loss, applied a chi-square test to determine significance between what was observed and what was expected. Our null hypothesis was that the forest cover was equally distributed over the topographic and distance categories. Statistical significance was set at an alpha level equal to 0.05 (Zar 1996).

\subsubsection{Aerial photograph interpretation}

To identify the spatial-temporal patterns of deforestation, we documented the changes associated with 11 forest fragments selected from field-based observations. Each fragment was smaller than 100ha, accessible, and had a landowner. For technical reasons we had to used two fragments situated in an adjacent basin.

Documentation was made through the interpretation of orthogonal black-and-white aerial photographs, relative to the years of 1969, 1976 and 1996. The 1969 photographs were produced by the North American Air Force (1:60,000 scale); 1976 photographs, by the Fundação para o Desenvolvimento da Região Metropolitana do Rio de Janeiro 
(FUNDREM) (1:40,000 scale); and 1996 photographs, by the Fundação CIDE-RJ (1:20,000 scale). The stereoscopic interpretation process was developed through the usual phases of detection, recognition/identification, delimitation, analysis and classification, using as main differentiation elements, tonality and texture (Marchetti 1986). The 1996 photos served as the base map.

\subsubsection{Farm-level analysis}

Farm-level survey complemented remote sensing analysis by identifying the spatial configuration associated with socio-economic practices of land appropriation and land use from 1969 to 1996. To evaluate the socio-economic influence on deforestation, we examined the spatial configurations of clearing sequences and the historical and geographical characteristics of the land-use in the studied area during a period of about 30 years. The analysis involved field surveys to identify and map the current human settlement patterns of immediate vicinities of the studied fragments. From these surveys, we have reconstructed the socio-historical processes that created the observed pattern.

Characterization of human settlement only occurred for rural land property since it has been recognized in the literature as a crucial variable for identifying land use forms and changes (see Kindscher and Scott 1997; Crow et al. 1999; Lovett-Doust and Kuntz 2001; Chidumayo 2002). For analysis purposes, the context of a forest fragment corresponded to boundaries of land properties containing the fragment totally or partially. This context was called the vicinity area and was characterized for each of the 11 fragments. To characterize property ownership and area we used the classification of the Instituto Nacional de Colonização e Reforma Agrária (INCRA) (INCRA 2004).

Land ownership and use data was obtained by interviewing landowners or authorized personnel, mainly asking about time of ownership, frequency of occupancy (year round or only weekends), presence of pets (especially dogs and cats), types and area for land uses, number of workers, technology used, annual yield, and hunting habits. Interviews were conducted between September 2000 and April 2001 for 15 of the 17 properties located around forest fragments studied (vicinity areas). These two properties were omitted in vicinity areas 5 and 6 because of the absence of landowners. To characterize the urban settlement, we made informal random interviews.

Once characterized, land-use patterns were related to the socio-economic historical processes, which occurred in the study area for the period from 1969 to 1996. To define these processes, we used pertinent literature and interviews of key individuals who could narrate the history of the settlement processes and/or the development of some important economic activities in the region.

\section{RESULTS}

\subsection{Remote sensing analysis}

Forest cover increased up to an elevation of 80m (Table 1). Chi-square test showed that forest cover rate difference between the two topographic categories (below and above $80 \mathrm{~m}$ ) was significant $\left(\_2=34.54 ; \mathrm{p}<0.0006\right)$. The analysis demonstrated that the pattern of forest was confined primarily to higher terrain.

Photo-interpretation showed two well defined patterns of forest cover: 1) patches occurred on small hills and connected to the lowland forests; and 2) fragments were confined to hilltops but lowlands have been cleared. Thus, many current fragments were connected to the Serra do Mar patch whereas other were isolated fragments created in 1969 or through continued forest retraction. In geological terms, the $80 \mathrm{~m}$ elevation represented a local "base line" in the deforestation process; above this point, the forests were less affected by deforestation agents. Forest cover increased in relation to distance from roads (Table 2). Chi-square test showed that variation of forest cover in relation to distance from roads is significant ( $\_2=27.02$, p $<$ 
Table 1. Distributions of absolute and relative forest cover area in relation to elevation.

\begin{tabular}{l|c|c}
\hline Altitude (m) & Forest cover area (ha) & \% Forest \\
\hline $0-20$ & 826.7 & $11.53 \%$ \\
$20-40$ & 1006.8 & $13.10 \%$ \\
$40-60$ & 1279.0 & $18.86 \%$ \\
$60-80$ & 1222.4 & $23.61 \%$ \\
$80-100$ & 1225.8 & $29.46 \%$ \\
$100-120$ & 1046.6 & $31.64 \%$ \\
$120-140$ & 897.4 & $33.99 \%$ \\
$140-160$ & 827.6 & $36.79 \%$ \\
$160-180$ & 775.7 & $37.61 \%$ \\
$180-200$ & 719.6 & $37.02 \%$ \\
$200-300$ & 2977.3 & $35.43 \%$ \\
$300-400$ & 2441.4 & $33.27 \%$ \\
$400-500$ & 2140.8 & $33.07 \%$ \\
\hline
\end{tabular}

0.0014). Thus, forest cover was directly related to distance from roads, demonstrating the negative effect of roads on the presence of forests (Goosem 1997;
Forman and Deblinger 2000). An exception was the decline of cover at the $900-1000 \mathrm{~m}$ increment.

Table 2. Distributions of absolute and relative forest cover area in relation to distance from roads.

\begin{tabular}{l|c|c}
\hline Distance from roads (m) & Forest cover area (ha) & \% Forest \\
\hline $0-100$ & 611.0 & $12.10 \%$ \\
$100-200$ & 784.4 & $16.73 \%$ \\
$200-300$ & 951.8 & $21.68 \%$ \\
$300-400$ & 1086.2 & $26.25 \%$ \\
$400-500$ & 1134.9 & $29.23 \%$ \\
$500-600$ & 1126.8 & $31.60 \%$ \\
$600-700$ & 1098.2 & $33.57 \%$ \\
$700-800$ & 1103.5 & $36.40 \%$ \\
$800-900$ & 1055.6 & $38.27 \%$ \\
$900-1000$ & 983.0 & $39.35 \%$ \\
\hline
\end{tabular}

Forest cover was significantly higher at $100 \mathrm{~m}$ distant from rivers ( $\left.\_2=139,00 ; \mathrm{p}<0.0001\right)$. More than $80 \%$ of the forest cover was concentrated within $200 \mathrm{~m}$ of rivers (Table 3). The higher forest cover rate associated with rivers proximity was probably due to the reticular drainage system, which presents a higher channel density in the hillier compartments. In some respects, this pattern was associated with the general pattern of forest confinement to landscape portions above $80 \mathrm{~m}$ of elevation. 
Combining sensors in landscape ecology: imagery-based and farm-level analysis in the study of human-driven forest fragmentation Diogo de Carvalho Cabral, Simone R. Freitas, Judith Tiomny Fiszon

Table 3. Distributions of absolute and relative forest cover area in relation to distance from drainage channels.

\begin{tabular}{l|c|c}
\hline Distance from drainage channels (m) & Forest cover area (ha) & \% Forest \\
\hline $0-100$ & 20396.9 & $43.48 \%$ \\
$100-200$ & 4905.5 & $37.45 \%$ \\
$200-300$ & 324.2 & $6.56 \%$ \\
$300-400$ & 15.2 & $0.36 \%$ \\
$400-500$ & 10.8 & $0.27 \%$ \\
$500-600$ & 0.5 & $0.01 \%$ \\
\hline
\end{tabular}

Another factor that leads to the maintenance of forests close to rivers seemed to be the environmental legislation, which was perhaps being applied in the Guapiaçú basin. According to CONAMA (Conselho Nacional do Meio Ambiente) Resolution $\mathrm{n}^{\circ}$ 09/96, riparian forests are considered corridors linking forest remnants, thus increasing landscape connectivity (Rede de Ongs da Mata Atlântica et al. 2001). For that matter, riparian forests, river borders, fountainheads and roof ridges around lakes and lagoons are protected by the environmental legislation and considered permanently preserved areas by the Environmental Crimes Act, the Forest Code and CONAMA Resolution no 4/85.

Overall, forest fragmentation pattern of Guapiaçú river basin appeared to be associated with topography, road network and drainage network distributions. Thus, remote sensing analysis could show where forest occurs and what the main fragmentation agents are.

\subsection{Farm-level analysis}

Following INCRA’s classification, the area of rural land properties less than 14ha (for Cachoeiras de Macacu) and less than 10ha (for Guapimirim) were considered as micro properties (INCRA 2004). Small properties were those properties with 14-56ha (for Cachoeiras de Macacu) and with 10-40ha (for Guapimirim), whereas medium properties had 56210ha and 40-150ha, and those larger than 210ha and 150ha, respectively, were classified as large properties (INCRA 2004).
Based on this classification, we identified three patterns of vicinity area (VA):

- VA composed of a single large rural property, which often contained the entire fragment (type 1);

— VA composed of more than one small or medium rural property and the fragment had multiple owners (type 2);

- VA composed of a mixture of urban allotments and small or medium rural properties and ownership patterns were similar to the previous type (type 3).

These different land property sizes implied distinct land uses and relations with the forest fragment (Table 4). Human settlement patterns originated from three coarse scale historical processes in the studied area: 1) the national public road system expansion and the upcountry settlement movement in southeastern Brazil, 2) the public policy of rural settlement executed by the Instituto Nacional de Colonização e Reforma Agrária (INCRA) and 3) "rich suburbanization" of Rio de Janeiro city, carried out through the construction/acquisition of occasionaluse residences by medium-upper urban classes with recreational objectives.

Using these historical settlement processes in association with the vicinity area's current patterns and the spatial configuration of forest patches, we identified two socio-spatial patterns whose joint 
effects explained current fragmentation of the forest landscape. The first one was associated with VAtype 1 , which is composed of a single large rural property, which often contained the entire fragment. The second one resulted from land appropriation and settlement by urban allotments and/or small or medium rural properties. This second pattern consisted of subsistence agriculture induced by INCRA's colonization model and occasional-use residency (weekend-recreation houses). The second pattern was composed of VA's type 2 and 3 (Table 4).

The first deforestation pattern was derived from the implantation of agricultural practices inside the limits of a large rural property (Figure 2). This spatial organization established agricultural areas, cattle raising areas, storehouses, habitations and other built environment modalities that removed the forest cover. In addition, these economic elements were connected among themselves and with adjacent parcels through a road system that connected every part of the farm as well as other farms through the regional highway. These local non-paved roads played a fundamental role in the dynamics of human settlement and conversion of forested lands by acting as linear deforestation elements. Beginning from the regional highway, roads expanded along the lowlands, progressively circumscribing the small hills. Once individualized as a kind of "deforestation cell", the small hills began to be settled from the foot hill up to an average elevation of 60 to $80 \mathrm{~m}$, approximately the elevation of existing forest. In this case, the forest fragments were located along ridges and hilltops and were permanently preserved areas (see Reis et al. 2002). Furthermore, the landowner generally did not have interest or intentions to exploit the fragment forest resources. In some cases, however, the landowner allowed his employees to extract forest resources or, because of the lack of security, allowed the patch to be exploited by other people.

Table 4. Settlement and land-use patterns around forest fragments (vicinity areas). Source: Cabral and Fiszon 2004 (modified).

\begin{tabular}{|c|c|c|c|}
\hline \multirow[t]{2}{*}{ Settlement variables } & \multicolumn{3}{|c|}{ Fragment vicinity area } \\
\hline & Type I & Type II & Type III \\
\hline $\begin{array}{l}\text { (1) Size and number } \\
\text { of land properties }\end{array}$ & One large land property & Many small land properties & $\begin{array}{l}\text { Medium land property(ies) } \\
\text { neighboring urban lots }\end{array}$ \\
\hline \multirow[t]{4}{*}{ (2) Dwellings use } & \multirow[t]{2}{*}{ Owners: occasional use } & \multirow[t]{2}{*}{ Owners: occasional or continuous } & (a) Rural properties \\
\hline & & & $\begin{array}{l}\text { Owners: occasional } \\
\text { Employees: continuous }\end{array}$ \\
\hline & \multirow[t]{2}{*}{ Employees: continuous use } & \multirow{2}{*}{$\begin{array}{l}\text { Employees (when they exist): } \\
\text { continuous use }\end{array}$} & (b) Urban lots \\
\hline & & & $\begin{array}{l}\text { Continuous and occasional use } \\
\text { (some with dwellings for employees) }\end{array}$ \\
\hline \multirow[t]{4}{*}{ (3) Land use } & \multirow{4}{*}{$\begin{array}{l}\text { Cattle raising yielding milk and } \\
\text { meat, diverse kinds of farming } \\
\text { (including subsistence and for } \\
\text { cattle feed) }\end{array}$} & \multirow{4}{*}{$\begin{array}{l}\text { Cattle raising yielding milk (small herd) } \\
\text { and subsistence farming }\end{array}$} & (a) Rural properties \\
\hline & & & $\begin{array}{l}\text { Cattle raising yielding milk and meat, } \\
\text { subsistence and cattle feed farming, } \\
\text { and small horticulture }\end{array}$ \\
\hline & & & (b) Urban lots \\
\hline & & & Gardens \\
\hline \multirow{4}{*}{$\begin{array}{l}\text { (4) Obedience to } \\
\text { the Forest Code }\end{array}$} & \multirow{4}{*}{$\begin{array}{l}\text { Fulfill the legal requirements } \\
\text { ( } 20 \% \text { of the land property is } \\
\text { reserved for permanent forest } \\
\text { conservation) }\end{array}$} & \multirow{4}{*}{$\begin{array}{l}\text { Conservation areas were delimited } \\
\text { by INCRA technicians in the } \\
\text { settlement process }\end{array}$} & (a) Rural properties \\
\hline & & & $\begin{array}{l}\text { Fulfill the legal requirements } \\
\text { ( } 20 \% \text { of the land property is reserved } \\
\text { for permanent forest conservation }\end{array}$ \\
\hline & & & (b) Urban lots \\
\hline & & & Not surveyed \\
\hline
\end{tabular}


The second deforestation pattern originated from the partitioning of a sole fragment into multiple owners (Figure 3). In this case, ownership was generally to provide lodging for their families, thus there was a higher density of houses than in the previous pattern. Although these houses were generally built along the foothills, forest cover also was confined to topographic compartments above $80 \mathrm{~m}$. Associated with the houses vegetable and flower gardens or small pastures were established which provided for household subsistence.

\section{DISCUSSION: METHODOLOGICAL LINKAGES OF REMOTE SENSING AND FARM-LEVELANALYSIS}

Despite the creation of distinct vicinity areas, both deforestation patterns caused, at the landscape level, forest cover to progressively retract to above $80 \mathrm{~m}$. From a historical perspective, this land conversion pattern represented a forest cover reversal. Before the wetlands were drained during the 1940s and 1950s, almost half of the coastal plain area (approx. 9,000 $\mathrm{km}^{2}$ ) was flooded in the rainy periods. This condition impeded or at least severely impeded the settlement of lowlands and restricted population growth to higher landscape, that is, the top of small hills (Mendes 1950). Therefore, the current forest cover was, in the past, the more disturbed areas. Thus, farm-level analysis could show how and why the forest fragmentation pattern occurs, explaining how the main fragmentation agents act. Moreover, how the forest fragmentation pattern changes in time could be explained combining both sensors (photo interpretation and socio-economic survey).

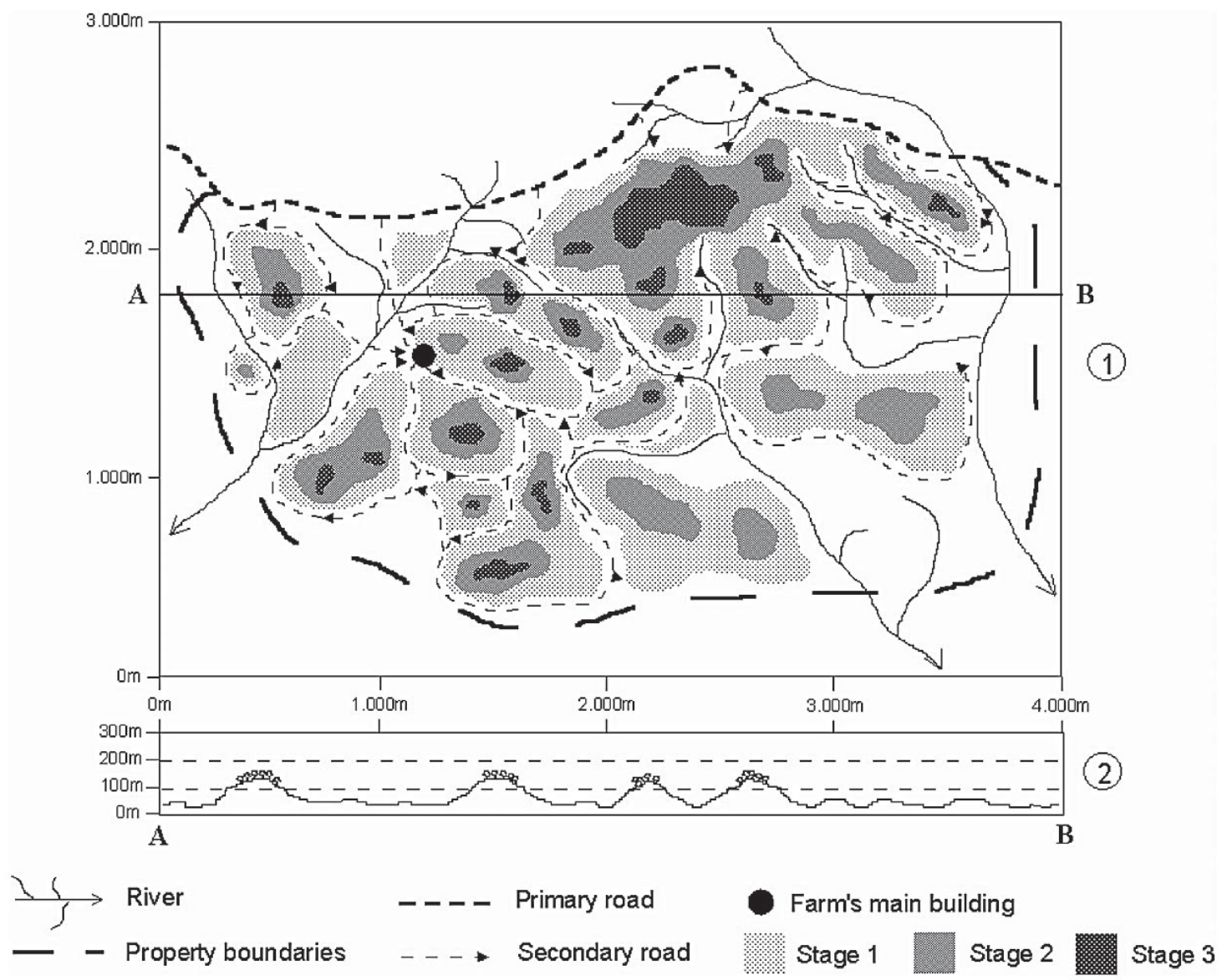

Figure 2. Chart (1) and cross section (2) scheme of large farms deforestation pattern in the Guapiaçú basin, Brazil. Patch dynamics is described by fragmentation stages 1 (for instance, 1969), 2 (1976) and 3 (1996). Cross section A-B shows remnant patches confined primarily to higher terrain in 1996. Modified from Cabral and Fiszon (2004). 
In the study of Guapiaçú basin, remote sensing analysis showed that forest was concentrated in those areas topographically elevated and distant from roads from 1969 until now. Then, remote sensing analysis explained to what extent and where real forested landscapes changed. Notwithstanding, the explanation of how and why this pattern required an understanding of socio-economic factors, which were derived from social field-based data surveys. In essence, landscape elements (e.g. roads and cleared lands) can only be interpreted if related to agents of change and social contexts which produced and used them in different historical periods.

The example of roads is emblematic of using only remote sensing data. Restricting the analysis only to spatial-temporal patterns of road construction (e.g., presence and absence of roads from 1969 to 1996) we cannot capture the crucial role of terrestrial routes that of facilitating socio-economic flows (commodities, services and people) and settlement of the territory. The opening of new regional roads must be considered in relation to the historical moment of Brazilian economy and society. Currently, the economic development strategy involved the investment of a much greater part of the national product in capital formation. The Brazilian government has never taken an attitude of gaining such resources through taxes. Citizens reacted by stocking their resources in the form of commodities which at least compensates for the devaluation of money. One such commodity was rural land property, traditionally the preferred investment form of the upper class and, now, increasingly the speculation of urban middle classes (Dean 1996). This is the wider scene in which the "rich suburbanization" process of the city of Rio de Janeiro referred to above occurred and, consequently, certain landscape dynamics were generated.

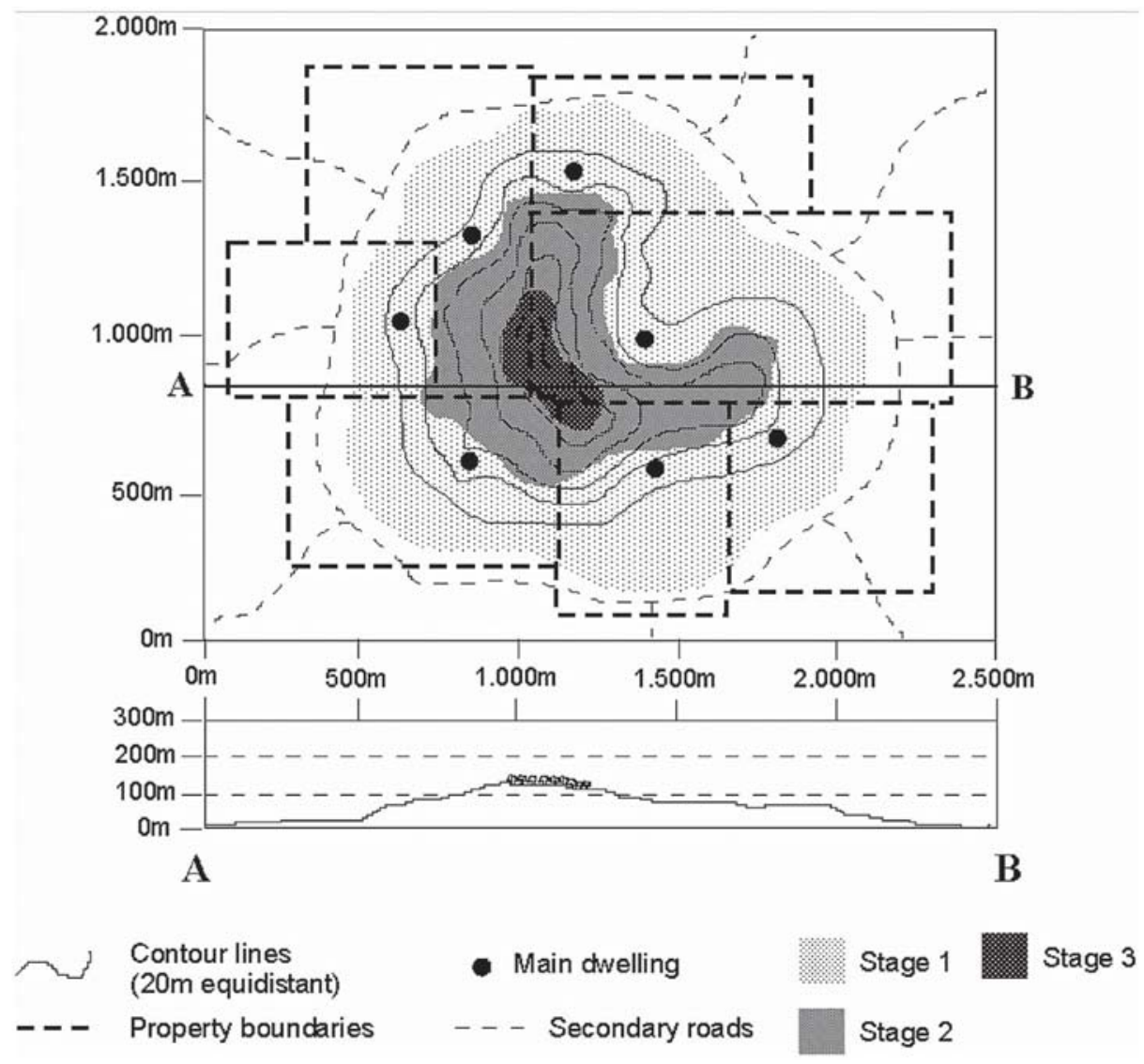

Figure 3. Chart (1) and cross section (2) scheme of the deforestation pattern associated to small/medium farms or urban lots in the Guapiaçú basin, Brazil. Patch dynamics is described by stages 1, 2 and 3. Cross section A-B shows topography and remnant patches in 1996. Modified from Cabral and Fiszon (2004). 
The ecological effects of roads can be felt in terrestrial ecosystems, substantial distances from the road, creating habitat fragmentation and facilitating ensuing fragmentation through support of human exploitative activities. Thus, because the nature and extent of land-use tend to be highly correlated with road networks, it is impossible to separate direct ecological effects of roads from those accompanying land uses (Trombulak and Frissel 2000). According to Grainger (1993), the increased accessibility induced by road construction (or improvement such as pavement or enlargement of the existing ones) was a significant factor that contributed to deforestation. This connection became evident in the study of Guapiaçú basin. Between late 1950s and beginning of the 1960s, the two regional roads accessing the area (BR-116 and RJ-122) were paved, which accelerated settlement process. According to the data provided by the Guapimirim district government, only six concessions for land division were officially registered in 1949. Between 1951 and 1959, the number of concessions tripled, with most occurring along new roads (Cabral and Fiszon 2004). These new settlement drivers created the need for the construction of subsidiary road networks which became progressively more complex (that is to say, connected). The addition of new roads and concessions played a formidable role in the exacerbating the rate of deforestation and fragmentation (Cabral and Fiszon 2004).

The central methodological point here is that landscape elements (fields, roads, forests, habitations, hedgerows, etc.) never have an independent effect but are part of the wider movement of society, or, more specifically, of its diverse actors which utilize those material elements. As Baker (1989) concludes, rather than a lack of technology to develop and operate mathematical models, the most important limit to the improvement of our understanding about landscape change processes may be a lack of knowledge of how and why landscape changes and how to incorporate such knowledge in useful models. Obtaining such knowledge requires a better comprehension of why people act as they do with regard to the piece of environment at their disposal. It is necessary, hence, to understand the relation between the dynamics of landscape elements and the social, political and economic dynamics of human beings. Consequently, remote observations of land-cover may show the footprints of agricultural intensification, urbanization and road development; observations of vegetation density may be related to the effects of fertilization, irrigation, and other agricultural practices; and observations of new building construction may be linked to the effects of local policies on land use and property taxation (Rindfuss and Stern 1998).

Other studies clearly show the need for methodological interaction of remote sensed and socio-historical analysis. Studying the deforestation dynamics in two government colonization projects in the states of Acre and Rondonia (Brazilian Amazon), Fujisaka et al. (1996) applied a methodology based on the validation of field observations through Landsat image analysis. Imagery-based analysis confirms deforestation determinants obtained through data derived from interviews with colonists and from the behavior of forest clearing, highly associated with the proximity of main roads. Sierra and Stallings (1998) were only able to identify and understand the role of timber exploitation on the deforestation process in northeastern Ecuador through the assistance of an analysis at the level of household activities. Turner II et al. (2001) came to a similar conclusion but through a different approach. They started with reconstitution of the general socio-historical background (land-use and land-cover history) to identify the type and general location of forest changes. Nevertheless, the authors concluded that historical land-use reconstruction was not a satisfactory analysis of landscape changes, owing to their fine resolution. To solve this problem, they used Landsat images and aerial photographs to identify broad scale landscape changes.

Methodological differences related to the sequence of application of the remote sensed and socio-historical phases were possibly related to the different extents of the study areas. Turner II et al. (2001) studied an area of 22,000 km2, an area almost four times larger than the one studied by Sierra and Stallings (1998). This difficulty seemed to be inversely proportional to the difficulty of preliminary re- 
construction of the socio-historical background of an area. Reconstructing a land-use history of larger areas is easier than smaller ones because of the greater availability of bibliographic and historical records for board areas. This trend seems to fit conditions occurring in Latin American and may be applicable to other continents.

Based on the examples above, we developed two contrasting theoretical-methodological observations about linking between remote sensing and the field-based social survey in the study of forest change:

(1) Mechanisms of human production of the landscape should be acquired at least at the resolution coinciding with social factors affecting landscape change. In most cases of forest fragmentation, these factors were restricted to rural land properties. Thus, landscape analyses must develop a local history methodology, based on rural factors and their interactions, at a resolution to deduce deforestation agents;

(2) Although social field research can provide detailed, often historically informed treatments of events that are the cause of land-use and land-cover change in a particular place (e.g. Wood and Skole 1998), their results are locally restrictive due to the small and expensive sampling. These results may not be conducive for modeling landscape dynamics.

The challenge, then, is to use social patterns observed in the field as part of a spatial model in a bottom-up sense. At the same time, such a model should avoid using socioeconomic analysis only as a mechanism to validate remote sensing results.

\subsection{A merged analytical model for human-driven forest fragmentation}

We propose a methodological model that uses fragmentation patterns to help identifying socialeconomic processes that produced the patterns (Figure 4). Based on the terminology offered by Geoghegan et al. (1998), we propose an approach that provides a way to simultaneously "socialize the pixel” (i.e. signaling the underlying processes that give rise to land-use and land-cover change), and "pixelize the social" (i.e. proceeding empirical tests of hypotheses of human behavior or social structures using remotely sensed data).

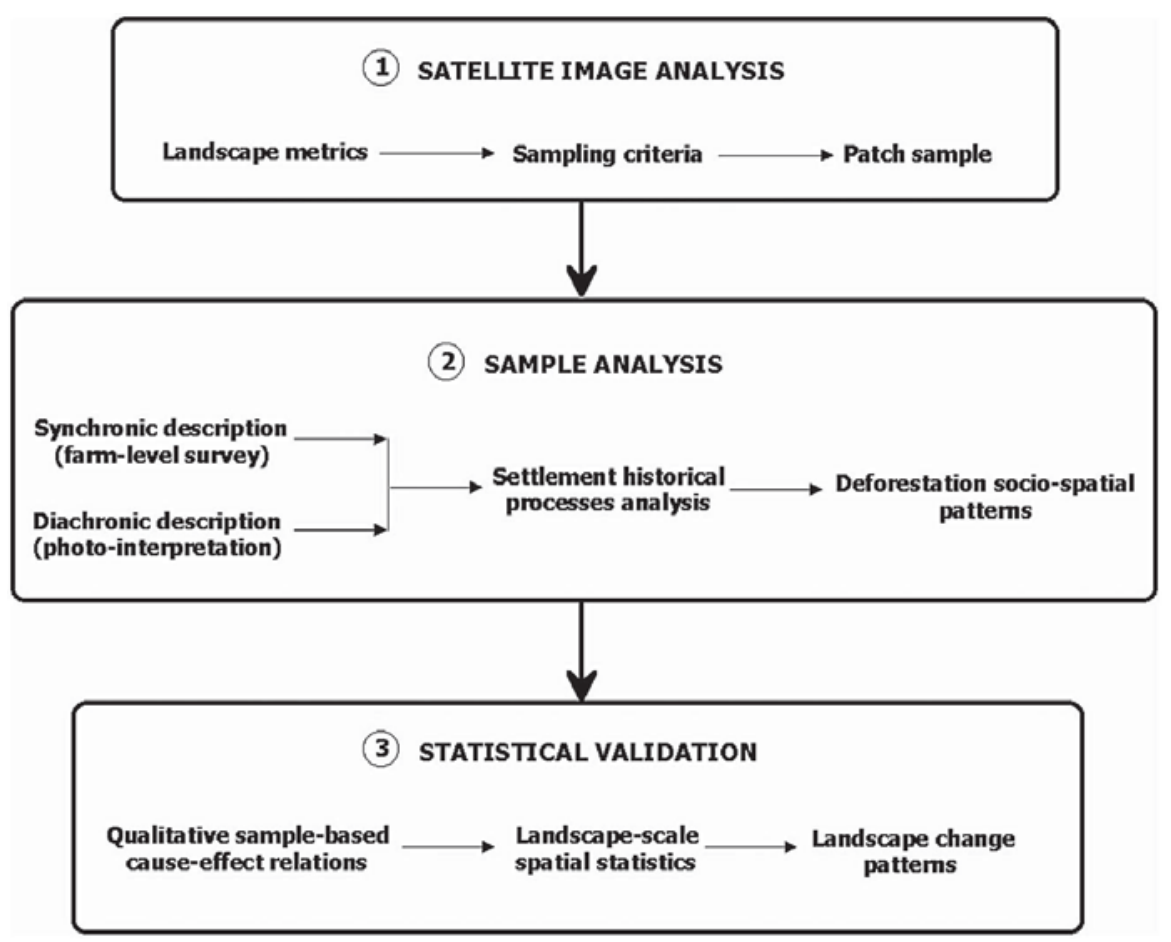

Figure 4. Methodological scheme associating remote sensing and field-based social survey. 
Such a model needs to move among three analytical levels: (1) fragment and its surroundings, encompassing rural properties, (2) landscape, encompassing a set of forest fragments, and (3) social-historical processes of human settlement (Gonçalves 1995; Reboratti 1999).

The landscape level identified landscape patterns and would be used to select field samples. Through remote sensing and GIS analyses, topological relationships among forest cover and distribution of roads, rivers, relief and land-uses are determined. Based on these relationships, sampling criteria can be developed related to human pressure or ecological effects of fragmentation processes. For instance, an interesting topic in community ecology is the isolation levels of forest fragmentation, evaluating its effects on fauna and flora. However, social studies could be interested in land-use types in nearby forest fragments, evaluating their effects on fragment metrics.

After study forest fragments are chosen, they must be extensively described, first synchronically, then diachronically. A synchronic description characterizes the land-use types bordering forest fragments and is obtained through queries and direct observations in rural properties. This description aims to investigate the relationships between the social factors and adjacent forest fragment from different social perspectives (economical, cultural, aesthetic and emotional), settlement time and alterations made by settlers. The diachronic description assesses the spatial-temporal configurations of the fragments. Satellites images could be used to reconstitute the history since the 1970's, and aerial photographs since the 1930's, in Brazil. This description must encompass fragment metrics and nearby land-use types, which could be related to deforestation, as roads, settlements, crops and utility lines.

Synchronic and diachronic descriptions can jointly provide geographical and social configurations associated with deforestation processes. The variation of configurations of human settlements and land-uses can cause differences between historical processes at global, national, regional and local scales (Cabral and Fiszon 2004). The social-historical context, however, can be reconstructed through literature searches, historical records and interviews of key individuals. To relate surroundings forest configurations to human settlement processes, we can generate qualitative-graphic models to further reduce the variation of observations by creating a set of simpler social, political and economic mechanisms that influence the deforestation process.

These qualitative models must support landscape level configurations as portrayed by satellite images. The causes and consequences of deforestation can be validated, based on topological associations as revealed by spatial statistics. Through validation, it is possible to jump from qualitative models to quantitative ones, thus achieving generalization on landscape dynamics. Following this procedure, hypotheses based on field observations, such as the restriction of forest in the hilltops and the progressive deforestation from roads could be categorically analyzed.

\section{CONCLUDING REMARKS}

Human-driven forest fragmentation is clearly a multidimensional problem. Thus, it cannot be suitably understood with "simple" (mono-dimensional) approaches such as imagery analysis, mathematical modeling or sociological studies (be it household-centered or macroeconomic). Each of these captures particular aspects of the phenomenon, but a far more comprehensive (complex) picture is provided by combining and integrating them. However, this task cannot be viewed as a simple mechanical juxtaposition of distinct methods and techniques there must be a theoretical construct framing it. We believe that this can be achieved, at least in this early stage of landscape research development, by using (i.e. engaging case studies) these "patchwork quilt" methodologies encompassing remote sensing and socio-economic data and, afterwards, identifying basic research practical problems. This is the first step towards a wider development of a much needed theoretically oriented merging of methodologies. 
By considering landscape changes in relation to human society and its history (Cabral and Fiszon 2004), the deforestation socio-spatial patterns approach has the potential to address crucial interrelated questions on how much, where, how and why landscapes changes. As Baker (1989) has suggested, modeling of particular change processes (case studies) could lead to "general modules" (change functions) interchangeable among models. These algorithms can be derived from deforestation spatial dynamics suggested by ideographic case studies. In this sense, they could support the generation of wider models and theories of landscape dynamics. Moreover, because deforestation patterns differently influence natural communities, these general components could include other aspects of landscape change, such as biodiversity loss. Thus, we proposed a methodological model that uses fragmentation patterns to help identifying social-economic processes that produced those patterns. Using synchronic and diachronic descriptions we can jointly provide geographical and social configurations associated with deforestation processes.

\section{REFERENCES}

Almeida, A.L.O. (1992) The colonization of the Amazon. Austin, USA: University of Texas Press.

Almeida, F.M. \& Carneiro, C. (1998) Origem e evolução da Serra do Mar. Rev. Bras. Geociências 28: 135-150.

Amador, E.S. (1997) Baía de Guanabara e ecossistemas periféricos: homem e natureza. Rio de Janeiro, Brazil: author's edition.

Andersen, L.E., Granger, C.W. \& Reis, E.J. et al. (2002) The dynamics of deforestation and economic growth in the Brazilian Amazon. Cambridge, UK: Cambridge University Press. 259p.

Azevedo, C.M.A. (2000) A decisão de preservar: $a$ mata ripária do Jaguari-Mirim, SP. São Paulo, Brazil: Annablume.
Baker, W.L. (1989) A review of models of landscape change. Landscape Ecology 2: 111-133.

Baskent, E.Z. (1999) Controlling spatial structure of forested landscapes: a case study towards landscape management. Landscape Ecology 14: 83-97.

Batistella, M., Robeson, S. \& Moran, E.F. (2003) Settlement design, forest fragmentation, and landscape change in Rondônia, Amazônia. Photogramm. Eng. Remote Sens. 69: 805-812.

BRASIL (1998) Primeiro relatório nacional para a conservação da diversidade biológica. Brasília, Brazil: MMA. 283p.

Brondizio, E. (1996) Land cover in the Amazon estuary: linking the thematic mapper with botanical and historical data. Photogramm. Eng. Remote Sens. 62: 921-929.

Cabral, D.C. \& Fiszon, J.T. (2004) Padrões sócioespaciais de desflorestamento e suas implicações para a fragmentação florestal: estudo de caso na bacia do rio Macacu, RJ. Scientia Forestalis 66: 13-24.

Cerqueira, R., Brant, A., Nascimento, M.T. \& Pardini, R. (2003) Fragmentação: alguns conceitos. In: Fragmentação de ecossistemas: causas, efeitos sobre a biodiversidade e recomendações de políticas públicas, ed. D.M. Rambaldi \& D.A.S. Oliveira, pp. 23-40. Brasília, Brazil: MMA/SBF.

Chidumayo, E.N. (2002) Changes in miombo woodland structure under different land tenure and use systems in Central Zambia. J. Biogeogr. 29: 16191626.

Collinge, S.K. (1995) Spatial arrangement of patches and corridors in the landscape: consequences for biological diversity and implications for landscape architecture. Ph.D. Dissertation. Cambridge, USA: Harvard University.

Collinge, S.K. (1996) Ecological consequences of habitat fragmentation: implications for landscape 
Combining sensors in landscape ecology: imagery-based and farm-level analysis in the study of human-driven forest fragmentation Diogo de Carvalho Cabral, Simone R. Freitas, Judith Tiomny Fiszon

architecture and planning. Landscape Urban Plann. 36: 59-77.

Crow, T.R., Host, G.E. \& Mladenoff, D.J. (1999) Ownership and ecosystem as sources of spatial heterogeneity in a forested landscape, Wisconsin, USA. Landscape Ecol. 14: 449-463.

Dean, W. (1996) With broadax and firebrand: the destruction of the Brazilian Atlantic Forest. Berkeley, USA: University of California Press.

Drummond, J.A. (1997) Devastação e preservação ambiental no Rio de Janeiro. Niterói, Brazil: EdUFF.

Fahrig, L. (2003) Effects of habitat fragmentation on biodiversity. Ann. Rev. Ecol. Syst. 34: 487-515.

Fiszon, J.T. \& Cabral, D.C. (2004) Os efeitos ambientais das casas de veraneio nas periferias metropolitanas: o caso do município de Guapimirim (RJ). Proceedings of the 1st Congresso Interamericano de Saúde Ambiental. Porto Alegre, Brazil: Associação Interamericana de Engenharia Sanitária e Ambiental.

Fonseca, G.A.B. (1985) The vanishing Brazilian Atlantic forest. Biol. Conserv. 34: 17-34.

Forman, R.T.T. \& Deblinger, R.D. (2000) The ecological road-effect zone of a Massachusetts (U.S.A.) suburban highway. Conserv. Biol. 14: 3646.

Forman, R.T.T. (1995) Land mosaics: the ecology of landscapes and regions. Cambridge, UK: Cambridge University Press.

Foster, D.R. (2002) Insights from historical geography to ecology and conservation: lessons from the New England landscape. J. Biogeogr. 29: 12691275.

Franklin, J.F. \& Forman, R.T.T. (1987) Creating landscape patterns by forest cutting: ecological consequences and principles. Landscape Ecology 1: 5-18.
Freitas, S.R. \& Shimabukuro, Y.E. (in press) Diagnosing tropical forests through remote sensing. In: New Research on Forest Ecology, ed. A.P. Parks. Hauppauge, USA: Nova Science Publishers.

Freitas, S.R. (2004) Modelagem de dados espectrais na análise de padrões de fragmentação florestal na bacia do rio Guapiaçú (RJ). PhD Thesis. Rio de Janeiro, Brazil: Instituto de Geociências/Universidade Federal do Rio de Janeiro. 373p.

Freitas, S.R., Mello, M.C.S. \& Cruz, C.B.M. (2005) Relationships between forest structure and vegetation indices in Atlantic Rainforest. Forest Ecology and Management_218: 353-362.

Fujisaka, S., Bell, W., Thomas, N., Hurtado, L. \& Crawford, E. (1996) Slash-and-burn agriculture, conversion to pasture, and deforestation in two Brazilian Amazon colonies. Agriculture, Ecosystems and Environment 59: 115-130.

Geoghegan, J., Pritchard Jr., L., Ogneva-Himmelberger, Y. et al. (1998) 'Socializing the pixel' and 'pixelizing the social' in land-use and land-cover change. In: People and pixels: Linking remote sensing and social sciences, ed. D. Liverman, E.F. Moran, R.R. Rindfuss et al. Washington, D.C., USA: National Academy Press.

Gonçalves, C.W.P. (1995) Formação sócio-espacial e questão ambiental no Brasil. In: Geografia e meio ambiente no Brasil, ed. B.K. Becker et al. São Paulo, Brazil: Hucitec.

Goosem, M. (1997) Internal fragmentation: the effects of roads, highways, and powerline clearings on movements and mortality of rainforest vertebrates. In: Tropical forest remnants: ecology, management, and conservation of fragmented communities, ed. W.F. Laurance \& R.O. Bierregaard Jr., pp. 241-255. Chicago, USA: University of Chicago Press.

Grainger, A. (1993) Controlling tropical deforestation. London, UK: Earthscan. 310pp. 
Gustafson, E.J. \& Crow, T.R. (1994) Forest management alternatives in the hoosier-national-forest. J. Forestry 92: 28-29.

Hansen, A., Urban, D.L. \& Marks, B. (1992) Avian community dynamics: the interplay of landscape trajectories and species life histories. In: Landscape boundaries: consequences for biotic diversity and ecological flows, ed. A. Hansen \& di Castri, pp. 170-195. New York, USA: Springer.

Hargis, C.D., Bissonette, J.A. \& David, J.L. (1998) The behaviour of landscape metrics commonly used in the study of habitat fragmentation. Landscape Ecol. 13: $167-186$.

IBGE (1991) Manual técnico da vegetação brasileira. Rio de Janeiro, Brazil: IBGE. 92p.

IBGE (2003) Sistema de Recuperação Automática - SIDRA [online]. http://www.sidra.ibge.gov.br . Acessed in 04/13/2003.

INCRA (2004) Indicadores cadastrais [online]. http:/ /www.incra.gov.br/_htm/serveinf/_htm/indic.htm\# indic2. Accessed in 09/28/2004.

INPE/DPI (2004) SPRING user's manual [online]. http://www.dpi.inpe.br/spring/english/manuals.html. Accessed in 04/25/2004.

Irwin, E.G. \& Bockstael, N.E. (2002) Interacting agents, spatial externalities and the evolution of residential land use patterns. J. Econ. Geogr. 2(1): 3154.

Kahn, J.R. \& McDonald, J.A. (1997) The role of economic factors in tropical deforestation. In: Tropical forest remnants: ecology, management, and conservation of fragmented communities, ed. W.F. Laurance \& R.O. Bierregaard Jr., pp. 13-28. Chicago, USA: University of Chicago Press.

Kindscher, K. \& Scott, N. (1997) Land ownership and tenure of the largest land parcels in the Flint Hills of Kansas, USA. Nat. Areas J. 17: 131-135.
Krutilla, K., Hyde, W.F. \& Barnes, D. (1995) Periurban deforestation in developing countries. Forest Ecology and Management 74: 181-195.

Li, H., Franklin, J.F., Swanson, F.J. \& Spies, T.A. (1993) Developing alternative forest cutting patterns: a simulation approach. Landscape Ecol. 8: 63-75.

Lillesand, T.M. \& Kiefer, R.W. (1994) Remote sensing and image interpretation. New York, USA: John Wiley and Sons. 750p.

Lovett-Doust, J. \& Kuntz, K. (2001) Land ownership and other landscape-level effects on biodiversity in southern Ontario's Niagara Escarpment Biosphere Reserve, Canada. Landscape Ecol. 16: 743-755.

Marchetti, D.A.B. (1986) Princípios de fotogrametria e fotointerpretação. São Paulo, Brazil: Nobel. 257p.

Marquete, C.M. (1998) Land use among small farmer settlers in the northeastern ecuadorian Amazon. Human Ecol. 26: 573-598.

McIntyre, S. \& Hobbs, R. (1999) A framework for conceptualizing human effects on landscapes and its relevance to management and research models. Conservation Biology 13: 1282-1292.

Mendes, R.S. (1950) Paisagens culturais da Baixada Fluminense. São Paulo, Brazil: Universidade de São Paulo.

Mertens, B., Sunderlin, W.D. \& Ndoye, O. (2000) Impact of macroeconomic change on deforestation in South Cameroon: integration of household survey and remotely-sensed data. World Dev. 28: 983-999.

Metzger, J.P. (2001) Effects of deforestation pattern and private nature reserves on the forest conservation in settlement areas of the Brazilian Amazon. Biota Neotr. 1: 1-14.

Metzger, J.P. (2002) Landscape dynamics and equilibrium in areas of slash-and-burn agriculture with 
Combining sensors in landscape ecology: imagery-based and farm-level analysis in the study of human-driven forest fragmentation Diogo de Carvalho Cabral, Simone R. Freitas, Judith Tiomny Fiszon

short and long fallow period (Bragantina region, NE Brazilian Amazon). Landscape Ecology 17, 419-431.

Moran, E.F. \& Brondízio, E.S. (1998) Land-Use Change after Deforestation in Amazonia. In: People and Pixels: Linking Remote Sensing and Social Science, ed. D. Liverman, E.F. Moran, R.R. Rindfuss \& P.C. Stern, pp. 94-120. Washington, D.C., USA: National Academy Press, http://www.nap.edu/books/ 0309064082/html/.

Myers, N. (1988) Tropical deforestation and remote sensing. Forest Ecology and Management 23: 215225.

Mykra, S., Kurki, S. \& Nikula, A. (2000) The spacing of mature forest habitat in relation to species-specific scales in managed boreal forests in NE Finland. Annales Zoologici Fennici 37: 79-91.

Nimer, E. (1979) Climatologia do Brasil. Rio de Janeiro, Brazil: IBGE. 422p.

Oliveira-Filho, F.J.B. \& Metzger, J.P. (2006) Thresholds in landscape structure for three common deforestation patterns in the Brazilian Amazon. Landscape Ecology 21: 1061-1073.

Pardini R. (2004) Effects of forest fragmentation on small mammals in an Atlantic Forest landscape. Biodiversity and Conservation 13: 2567-2586.

Pax-Lenney, M., Woodcock, C.E., Macomber, S.A., Gopal, S. \& Song, C. (2001) Forest mapping with a generalized classifier and Landsat TM data. Remote Sens. Environ. 77: 241-250.

Pfaff, A.S.P. (1999) What drives deforestation in the Brazilian Amazon? J. Environ. Econ. Manage. 37: 26-43.

Pirnat, J. (2000) Conservation and management of forest patches and corridors in suburban landscapes. Landscape Urban Plan. 52: 135-143.

Rambaldi, D.M. \& Oliveira, D.A.S. (2003) Frag- mentação de ecossistemas: causas, efeitos sobre a biodiversidade e recomendações de políticas públicas. Brasília, Brazil: MMA/SBF. 510p.

Reboratti, C.E. (1999) Territory, scale and sustainable development. In: Sustainability and the social sciences, ed. E. Becker \& T. Jahn. London, UK: Zed Books.

Rede de Ongs Mata Atlântica, Instituto Socioambiental, Sociedade Nordestina de Ecologia (2001) Dossiê Mata Atlântica 2001: Projeto Monitoramento Participativo da Mata Atlântica. São Paulo, Brazil: Instituto Socioambiental. 407p.

Reis, M.S., Mariot, A., Conte, R. \& Guerra, M.P. (2002) Aspectos do manejo de recursos da Mata Atlântica no contexto ecológico, fundiário e legal. In: Sustentável Mata Atlântica: a exploração de seus recursos florestais, ed. L.L. Simões \& C.F. Lino, pp.159-171. São Paulo, Brazil: SENAC.

Rindfuss, R.R. \& Stern, P.C. (1998) Linking remote sensing and social science: the need and the challenges. In: People and pixels: Linking remote sensing and social sciences, ed. D. Liverman, E.F. Moran \& R.R. Rindfuss et al. Washington, D.C., USA: National Academy Press.

Schaeffer, R.E. (1970) Derrubada. In: Tipos $e$ aspectos do Brasil, pp.469-471. Rio de Janeiro, Brazil: FIBGE.

Shimabukuro, Y.E. \& Smith, J.A. (1991). The leastsquares mixing models to generate fraction images derived from remote sensing multispectral data. IEEE Trans. Geosc. Remote Sens. 29: 16-20.

Sierra, R. \& Stallings, J. (1998) The dynamics and social organization of tropical deforestation in northwest Ecuador, 1983-1995. Human Ecol. 26: 135161.

Sierra, R. (2000) Dynamics and patterns of deforestation in the western Amazon: the Napo deforestation front, 1986-1996. Applied Geography 20: 1-16. 
Skole, D. \& Tucker, C. (1993) Tropical deforestation and habitat fragmentation in the Amazon: satellite data from 1978 to 1988. Science 260: 1905-1910.

Souza, M.L. (2003) ABC do desenvolvimento urbano. Rio de Janeiro, Brazil: Bertrand Brasil.

Tanizaki, K. \& Moulton, T.P. (2000) A fragmentação da Mata Atlântica no Estado do Rio de Janeiro e a perda de biodiversidade. In: A fauna ameaçada de extinção do Estado do Rio de Janeiro, ed. H.G. Bergallo, C.F.D. Rocha, M.A.S. Alves \& M. Van Sluys, pp.23-35. Rio de Janeiro, Brazil: EdUERJ.

Trani, M.K. \& Giles, R.H. (1999) An analysis of deforestation: metrics used to describe pattern change. For. Ecol. Manage. 114: 459-470.

Trombulak, S.C. \& Frissel, C.A. (2000) Review of ecological effects of roads on terrestrial and aquatic communities. Conserv. Biol. 14: 18-30.

Turner II, B.L., Villar, S.C., Foster, D., Geoghegan, J., et al. (2001) Deforestation in the southern Yucatán peninsular region: an integrative approach. For. Ecol. Manage. 154: 353-370.

Uezu A., Metzger J.P. \& Vielliard J.M.E. (2005) Effects of structural and functional connectivity and patch size on the abundance of seven Atlantic Forest bird species. Biological Conservation 123: 507-519.

Wood, C.H. \& Skole, D. (1998) Linking satellite, census, and survey data to study deforestation in the Brazilian Amazon. In: People and pixels: Linking remote sensing and social sciences, ed. D. Liverman, E.F. Moran, R.R. Rindfuss et al. Washington, D.C., USA: National Academy Press.

Zar, J.H. (1996) Biostatistical analysis. New Jersey, USA: Prentice-Hall. 662p.

Zipperer, W.C. (1993) Deforestation patterns and their effects on forest patches. Landscape Ecol. 8: 177-184.

\section{ACKNOWLEDGEMENTS}

We would like to thank Marcia C. S. Mello, Leonardo B. Lignani and Carla B. M. Cruz for fruitful discussions. We thank PROBIO (PRONABIO/ MMA/GEF) that supported this study. This work is part of Simone Freitas Doctoral thesis, and we thank CAPES for the scholarship. We also thank FAPERJ for additional financial support and Dr. Wayne Zipperer (USDA Forest Service) for editorial comments. 